\title{
KONFERENZBEITRÄGE
}

WIENER SLAVISTISCHES JAHRBUCH, Band 55/2009, 7-12

(C) 2009 by Österreichische Akademie der Wissenschaften, Wien

ЛЮБКА ЛИПЧЕВА - ПРАНДЖЕВА

ХАЙНЦ МИКЛАС

\section{БЪЛГАРСКАТА КНИГА ОТВЬД БЪЛГАРИЯ Международна конференция в чест на 200-годишнината от излизането на първата печатна книга на новобългарски език}

Международната българистична конференция, състояла се във Виена на 25-ти и 26-ти май 2006 година, беше първият подобен форум в Института по славистика на Виенския университет. Вероятно изглежда странно, но в дългата история на института можем да проследим цяла поредица от симпозиуми по старобългаристика и общославистични конференции с българско участие, но няма да открием нито една конференция, чиято централна тема да е българското съвремие, българската книжовност и особено българската литература. Причините за това са преди всичко две - по-късната еманципация на българистиката като учебна специалност и продължилата дълго доминанта на езикознанието в института, с която той всъщност е и известен в научния свят. Като единствен предвестник на конференцията можем да отбележим Денят на българистиката, организиран от Х. Миклас през 2002 година като прелюдия към новата специалност българистика.

Поводът, който този път събра във Виена българисти от различни европейски ареали (Русия, Полша, Чехия, Германия, Франция, Австрия и България) е специален и звучи още в озаглавяването на конференцията: навършването на 200 години от появата на една толкова важна за българската култура книга сборника с поучителни слова Кириакодромион, сиреч Неделник на епископ Софроний от Враца. Отпечатването му в 1000 екземпляра в румънския град Римник отнема почти седем месеца - от 24 април до 25 ноември 1806 г. и е сьпроводено с множество трудности, които авторът преодолява с помощта на български и румънски дарители. Амбицията на автора - веднош да буде начало - 
осъществена и неслучайно неговият „Неделник“ стои и до днес във фокуса на многопосочни културологични изследвания. Филолози, историци, социолози и етнолози откриват в Софрониевия сборник своя разказ, своето конструиране на прехода на българската култура към модерността. Дори само фактът, че българският възрожденски читател изобретява отделни наименования за тази книга, които стилистично степенуват формите на общуване с нея (Неделник е името на богослужебната практика, а името Софроние отбелязва интимитета на битовото), е достатъчен, за да очертае значимостта на присъствието й в колективния живот. Многократно преиздавано и широко разпространено, Софронието се превръща в една от първите книги на българското масово споделяне, на колективното четене.

Виена на XIX-ти век е тясно свързана с интензивното разгръщане на този тип културно общуване в България и това бе другото основание юбилейната конференция да се проведе тук. През периода на Възраждането градът е найголемият център за българско книгопечатане извън пределите на Османската империя. Само до 1878 година, освобождението на България от османско владичество, във Виена излизат 334 български книги, свързани с имената на някои от най-значимите просветни дейци на България - Ив. Добровски, Хр. Г. Данов, Драган Манчов, Д. Войников, Илия Блъсков и редица други. Пьрвите книги са издадени в печатницата на Мехитаристите, от 1852 година с нарастването на обема на поръчките се предпочита модерната за времето техника на печатницата на Сомер, а през 1874 година Я. Ковачев и Хр. Г. Данов създават българска печатница във Виена. По искане на княз Дондуков-Корсаков през 1878 година печатницата е преместена в България, където се основават две печатници - в тогавашния културен център Пловдив и в София, столицата на новосъздадената държава. Неслучайно Ватрослав Ягич нарича Христо Г. Данов българския Гутенберг - до 1911 година книжната продукция на печатницата му наброява 9000 заглавия. Така българската печатница във Виена ляга в основата на модерното българско книгопечатане.

Този широк историографски план бе всъщност само една от посоките на диалога, осъществен на конференцията. Темата ѝ, Българската книга отвъд България, даде възможност да се проектират и да се мислят в единство множество полета на културна комуникация, свързани с битието на българската книга в чужд контекст - издателска и преводаческа дейност, променящи се механизми на разпространение и съхраняване, оценъчни реакции, емигрантска литература и др. Срещата на методологически различни нагласи и на различен тип професионална опитност (литературоведи, езиковеди, преводачи, библиотекари, историци, преподаватели и студенти слависти) позволи особения тон на конференцията - критично вглеждане и преосмисляне на тъкмо онези тези, които са се превърнали в общосподелима истина. В поздравителното си слово към участниците в конференцията X. Миклас зададе началото на тази диалогична атмосфера. Той очерта проблематичността на самото юбилейно честване 
- докато значимостта на Софрониевия Неделник в плана на българското културно битие е несъмнена, определянето му като „първата печатна книга на новобългарски език“ изисква прецизна оценка на езиковата му характеристика. По-ранните издания на първия български печатар Яков Крайков в основаната от Божидар Вукович венецианска печатница са издания на църковнославянски, но като езикова устроеност Неделникът на Софроний Врачански попада в конкуренцията на поне още две други книги: излезлият в Рим през 1651 г. Абагар на Филип Станиславов и Рибния буквар на Петър Берон, излязъл през 1824 г. в Лайпциг. Задълбочен коментар на въпроса доколко класифицирането на езика на Софроний Врачански като „новобългарски“ е основателно от езиковедска гледна точка предложи докладът на Хана Гладкова: Неделник на Софроний Врачански - огледало на езиковата ситуация през Възраждането (върху изданията om 1806, 1856 и 1865 г.). ${ }^{1}$ Въз основа на съпоставката на първопечатния текст с рькописната му редакция, с езика на другите произведения на Софроний и с Паисиевата История славяноболгарская Гладкова направи заключения за мястото на творбата в процеса на формирането на нормата на новобългарския книжовен език.

Проблемите на езика, но разбирани вече в плана на възможностите за културен трансфер, разтвориха друг тип дискусионно поле. За Клео Протохристова представянето на българската литература във въображаемото пространство на „световната литературна сцена“, позволява в еднаква степен оптимистично и песимистично ориентирано описание. Едната позиция избира да говори за множествеността на преводите, за присъствието на българската литература в университетски курсове извън България, за вписването й в различни енциклопедични справочници. Другата, обратно, забелязва спорадичността на преводите, зависимостта им от каноните, загубата на културни кодове и символни техники, съответно дистанцирането и изключването. Д. Камбуров коментира интеркултурната (не)конвертируемост през срещата на преводния текст с новия (чуждия) критически език, стабилизиран като специфична контекстуална норма. В англоезичните рецензии за творчеството на Г. Господинов интерпретациите на постмодерната нагласа на един български автор се движат между изненадата и пълната й неразчетеност. За смяната на езика като смяна на контекстно битие, но вече провокирана от личен авторов избор, говори и Л. Липчева.

Напрежението между преводимост и непреводимост Инна Пелева проектира в изненадващо различен ракурс - усетите за недостатъчност или за успешност на културния трансфер проявяват всъщност вътрешната самооценка, говорят за страха от чуждия поглед, но и за потребността от диалог. Непреводи-

1 За съжаление, по независещи от редакторите причини, докладите на Х. Гладкова, Д. Камбуров и Р. Кунчева останаха извън това издание. 
мостта, която неизбежно „нормализира“ в чуждия език проблематичния Бай Ганьо на Алеко Константинов, се преживява при всеки нов превод на произведението като културен шанс за българското. Докладът на Н. Капралова показа противоположната посока - прекаленото себехаресване, носталгиите като мотивация за превод, съчетани с политическа амбиция за представителност, могат да доведат до присъствие, в което българската литература отчасти или напълно е загубила себе си. Съпоставителният план, но разчетен вече от външна, небългарска, перспектива провокира основателността на травматичните усети за непълноценно присъствие или за затваряне на българската книга изцяло в родното пространство. Гр. Шват-Гълъбова предложи задълбочен разрез на типовете присъствие/отсъствие на българската литература в полския културен контекст. Праговете на достъп, положени в полската национална идея (XIX-ти век), в идеологическата инструментализация (измамният обем преводи по време на тоталитарния режим), днес са обвързани много повече с глобалните, цивилизационни промени, коригиращи мястото на книгата в живота на модерния човек. Новото, постгутенбергово битие на текста, в което достъпът на/до българската литература изглежда абсолютно освободен от централизации и йерархии проектира Л. Удолф. Преценени „отвън“, от Варшава и Дрезден, бъдещите шансове на българската литература изглеждаха еднакво заложени в способността й да провокира интелектуален диалог отвъд собствената си езиковост.

Докладът на П. Бахмайер напомни на всички участници, че политическите езици неизменно се стремят да изработват своето културно присъствие. Културните отношения между Австрия и България достигат най-интензивната си фаза през периода 1975-1981, когато председател на българския Комитет за култура е Людмила Живкова. Създава се Център по българистика, издава се списание „Славянски езици“, превеждат се представителни за българската идентичност текстове, излиза критичното издание на превода на Библията на Св. Методи и др. Историографският разказ за успешните стратегии за пребиваване на българската (социалистическа) култура предизвика диалог за паметта за социализма - напрегнат диалог, в който като опозиция на носталгиите прозвучаха и недоволството от настоящия аналитичен подход към близкото минало, и склонността към отказ от памет. Задочно в този диалог се включи и Ален Вюймен с доклад за френскоезичното издание на произведенията на Л. Генчев. Обявен за „враг на народа“ през 1952 г. по време на процесите срещу българските католици в Пловдив, този български автор, писал на френски език, лично присъства на конфискуването на ръкописите си. Изземването е извършено в дома му от политическата полиция и в резултат на донос. Л. Генчев възстановява текстовете си по памет между ноември 1973 г. и август 1980 г., но произведенията му още дълго ще продължават да отсъстват от витрината на българската книга. Отсъствията като идеологически обоснована издателска стратегия коментира и Н. Рандов. Едно пълно издание на дневника на Б. Делчев би конструирало памет, очевидно неудобна за днешни политически репрезентации в 
България. От друга страна, частичният, подбран превод на текста, предназначен за немскоезичната публика, би разсеял множество недоразумения и стереотипни представи, свързани с българската култура.

Изчистено от напреженията на актуалните властови символизации, библиотечното присъствие на българската книга изглеждаше особено успокоено, реализиращо може би най-пълноценното отвъдно битие. К. П. Моисси представи образа на българската възрожденска култура, който проектират българските книги, отпечатани във Виена през ХІХ-ти век и съхранявани във фондовете на Австрийската национална библиотека. Сред книгите, свързани с икономиката, моралистичните и религиозни текстове изпъква масивът на научнопопулярни издания и учебници, предназначени за различни възрастови групи. От периодиката до географските карти - каталозите говорят за любопитства и амбиции, но и за потенциала на една търсеща себе си духовна енергия. Каталозите на славистичната катедрена библиотека в Санкт-Петербургския университет съположиха друг образ. В доклада на Г. Крилова и О. Василева времевата проекция (от 40-те години на XIX-ти век до днес) отброява близо 8000 заглавия и реконструира интензивен, многопосочен диалог на интелектуалци, ярко контрастиращ на една отколешната (вътрешна) инерция за негативно оценностяване: „Ние нямаме нито Гетевия Вертер, нито Сервантесовия Дон Kuхот ...“.

Има една странна логика на научната ефективност, присъща на конференциите, и ние като организатори на международната българистична конференция във Виена бяхме предварително наясно с нейната неизбежност - колкото по-добре е организирана една конференция, толкова по-неподвластен на предварителния проект е нейният диалог. За съжаление, статиите, които предлагаме на читателите, не съдържат дискусионния фон, на който звучаха докладите. Надяваме се обаче, че публикуването ще им даде друг шанс - да провокират нови питания, нови отговори, а защо не и друг тип недоволства, свързани с присъствието на българската книга отвъд България.

Нашата конференция бе само началната точка на поредица от събития, обвързани с честването на юбилея и с предстоящото тогава влизане на България в нова обединена Европа. Бихме могли да го наречем „второто влизане“ с оглед на факта, че първото е осъществено още през 865 г. от княз Борис с въвеждането на християнството. С откриването на паметна плоча на мястото, където се е намирала печатницата на Я. С. Ковачев и Хр. Г. Данов, конференцията остави своя знак в една бъдеща карта на българските места в културното пространство на Виена. Студентите българисти (под научното ръководство на тогавашния гост доцент по българска литература към института Л. ЛипчеваПранджева) изработиха каталог на българските книги, издавани във Виена през XIX-ти век и съхранявани в Австрийската национална библиотека. Активната работа на колегите слависти от националните библиотеки в София и във Виена позволи през февруари 2007 този каталог да оживее в една изключително успешна изложба в тържествената зала на Хофбург. Тук е мястото да из- 
кажем специалната си благодарност към нашия основен партньор и съорганизатор на конференцията Б. Петранов, директор на Българския културен институт „Дом Витгенщайн“ - за неговата инициативност и за финансовата подкрепата, която той осигури за целия проект. Но преди всичко за гостоприемството и приятната работна атмосфера, които „Дом Витгенщайн“ предложи на участниците в конференцията.

Любка Липчева-Пранджева Faculty of Languages and Literature Plovdiv University „Paisii Hilendarski“ Tsar Asen St. 24, 4000 Plovdiv, Bulgarien 1lipcheva@abv.bg
Heinz Miklas

Institut für Slawistik der Universität Wien Universitätscampus AAKH, Hof 3 Spitalgasse 2, 1090 Wien, Österreich heinz.miklas@univie.ac.at 